\title{
KAJIAN YURIDIS TANGGUNG JAWAB PERDATA RUMAH SAKIT AKIBAT KELALAIAN DALAM PELAYANAN KESEHATAN
}

\author{
Dani Amalia Arifin \\ Magister Hukum Fakultas Hukum Universitas Jenderal Soedirman
}

\begin{abstract}
The hospital as one of the health facilities, in Act No. 44 of 2009 About a hospital divided by type of service and its management. The hospital implement all the activities of the health service, which involves a wide range of professions health workers at the hospital, using hardware and software related to technology, applying the management the management of the hospital in order to serve the patients as the Hospital service users. As one of the health facilities. The method used is the juridical approach to normative or legal research only examined the references so that it referred to legal research library. As for another approach used is the Analytical approach (Analytical Approach).

The results showed civil liability action over Hospital negligence of health workers at the hospital that caused harm to patients in accordance with the provisions of Section 1367 KUHPerdata paragraph (3) and article 46 of the Act Number 44 in 2009 about the hospital. The responsibility of the civil law the hospital due to the negligence of health workers at the hospital in the form of liability based on tort law and liability based on tort.
\end{abstract}

Key Word: careless, healty service, liability

Abstrak
Rumah Sakit sebagai salah satu sarana kesehatan, dalam UU No. 44 Tahun 2009 Tentang Rumah Sakit dibagi berdasarkan jenis pelayanan dan pengelolaannya. Rumah Sakit melaksanakan semua proses kegiatan pelayanan kesehatan, yang melibatkan berbagai profesi tenaga kesehatan di Rumah Sakit, menggunakan perangkat keras maupun perangkat lunak berkaitan dengan teknologi, menerapkan manajemen pengelolaan Rumah Sakit dalam rangka melayani pasien selaku pengguna jasa Rumah Sakit. ${ }^{1}$ Sebagai salah satu sarana kesehatan. Metode pendekatan yang digunakan adalah yuridis normatif atau penelitian hukum yang hanya meneliti bahan pustaka sehingga disebut juga penelitian hukum kepustakaan. Adapun pendekatan lain yang digunakan adalah pendekatan Analitis.

Hasil penelitian menunjukkan tanggung Jawab Perdata Rumah Sakit atas tindakan kelalaian tenaga kesehatan di Rumah Sakit yang menyebabkan kerugian pada pasien sesuai dengan ketentuan dari Pasal 1367 ayat (3) KUHPerdata dan Pasal 46 Undang-Undang Nomor 44 Tahun 2009 tentang Rumah Sakit. Tanggung jawab hukum perdata Rumah Sakit akibat kelalaian tenaga kesehatan berupa pertanggungjawaban berdasarkan perbuatan melawan hukum dan pertanggung jawaban berdasarkan wanprestasi.

Kata Kunci: kelalaian, pelayanan kesehatan, tanggung jawab

\section{PENDAHULUAN}

Rumah Sakit sebagai organisasi badan usaha di bidang kesehatan mempunyai peranan penting dalam mewujudkan derajat kesehatan masyarakat secara optimal. ${ }^{2}$ Rumah Sakit dalam Undang-Undang No. 44 Tahun 2009 Tentang Rumah Sakit adalah institusi pelayanan kese- hatan yang menyelenggarakan pelayanan kesehatan perorangan secara paripurna yang menyediakan pelayanan rawat inap, rawat jalan, dan gawat darurat. Pelayanan kesehatan paripurna adalah pelayanan kesehatan yang meliputi promotif, preventif, kuratif dan rehabilitatif. Anggaran dasar Perhimpunan

Endang Wahyati Yustina, 2012, Mengenal Hukum Rumah Sakit, Bandung, CV Keni Media, hal 75.

Setya Wahyudi, 2011, Tanggung Jawab Rumah Sakit Terhadap Kerugian Akibat Kelalaian Tenaga Kesehatan Dan Implikasinya, Jurnal Dinamika Hukum Fakultas Hukum Universitas Jenderal Soedirman Volume 11 No.3,hal.486. 
Rumah Sakit Seluruh Indonesia (Persi) BAB I Pasal 1 menyebutkan,"bahwa Rumah Sakit adalah suatu sarana dalam mata rantai system kesehatan nasional yang mengemban tugas pelayanan kesehatan untuk seluruh masyarakat". ${ }^{3}$ Kamus Besar Bahasa Indonesia mendefinisikan bahwa Rumah Sakit adalah, "gedung tempat merawat orang sakit atau gedung tempat menyediakan dan memberikan pelayanan kesehatan yang meliputi berbagai masalah kesehatan". ${ }^{4}$ Dengan demikian, Rumah Sakit adalah tempat untuk menyelenggarakan salah satu upaya kesehatan, yaitu upaya pelayanan kesehatan (health services). ${ }^{5}$

Berdasarkan jenis pelayanan yang diberikan Rumah Sakit dibagi menjadi Rumah Sakit Umum dan Rumah Sakit Khusus. Sedangkan berdasarkan pengelolaannya, Rumah Sakit dibagi menjadi Rumah Sakit publik dan Rumah Sakit privat. Berdasarkan data dari Kementerian Kesehatan Republik Indonesia Direktorat Jenderal Bina Upaya Kesehatan diketahui bahwa jumlah Rumah Sakit di seluruh Indonesia sebanyak 2401 Rumah Sakit. Berikut ini adalah data jumlah Rumah Sakit di Indonesia:

Dari data di atas, dapat diketahui bahwa jumlah Rumah Sakit baik milik pemerintah maupun swasta sudah cukup banyak. Bukan tidak mungkin di masa yang akan datang jumlah Rumah Sakit ini akan terus bertambah mengingat kebutuhan rakyat Indonesia akan sarana pelayanan kesehatan yang terus meningkat.

3 Endang Kusuma Astuti, 2009, Transaksi Terapeutik Dalam Upaya Pelayanan Medis Di Rumah Sakit, Bandung, PT Citra Aditya Bakti, hal. 51. Dikutip dari Panitia Etika Rumah Sakit, 1991, "Etika Rumah Sakit di Rumah Sakit Dr. Cipto Mangunkusumo", Jakarta, hal 1.

4 Amir Ilyas, 2014, Pertanggungjawaban Pidana Dokter Dalam Malpraktik Medik Di Rumah Sakit,Yogyakarta, Rangkang Education dan Republik Institute, hal9.

5 Endang Kusuma Astuti, Loc, Cit., hal 2.
Rumah Sakit merupakan tempat bekerjanya para tenaga profesional yang melaksanakan kegiatannya berdasarkan lafal sumpah dan kode etik profesinya. Oleh karena itu Rumah Sakit dituntut agar mampu mengelola kegiatannya, dengan mengutamakan pada tanggung jawab para profesional di bidang kesehatan, khususnya tenaga medis dan tenaga keperawatan dalam menjalankan tugas dan kewenangannya. ${ }^{6}$ Setiap tenaga kesehatan yang bekerja di Rumah Sakit harus bekerja sesuai dengan standar profesi, standar pelayanan Rumah Sakit, dan standar prosedur operasional yang berlaku, juga menjunjung tinggi etika profesi, menghormati hak pasien serta mengutamakan kepentingan pasien.

Tidak selamanya layanan medis yang diberikan oleh tenaga kesehatan di Rumah Sakit, dapat memberikan hasil sebagaimana yang diharapkan semua pihak. ${ }^{7}$ Ada kalanya dalam layanan tersebut terjadi kelalaian tenaga kesehatan yang menimbulkan malapetaka; seperti cacat, lumpuh atau bahkan meninggal dunia. ${ }^{8}$ Seperti halnya yang dialami oleh Shanti Marina warga Perumahan Bumi Karang Indah, Lebak Bulus Kecamatan Cilandak, Jakarta Selatan yang menderita kecacatan, yaitu suaranya menjadi sengau/bindeng setelah menjalani operasi amandel yang dilakukan oleh dr. Wardhani Sp.THT di Rumah Sakit Puri Cinere. Padahal sebelum operasi suara pasien dalam keadaaan baik/normal. Dalam gugatannya meminta pertanggungjawaban atas perbuatan

\footnotetext{
Setya Wahyudi, Loc.Cit., hal 348.

Ibid., hal 486.

lbid.,Seperti kasus yang dialami oleh Shanti Marina setelah menjalankan operasi amandel di Rumah Sakit Puri Cinere, ternyata suaranya menjadi bindeng. Lihat Bambang Heryanto, 2010, "Malpraktik Dokter dalam Perspektif Hukum", Jurnal Dinamika Hukum, Vol.10 No.2 Mei 2010, hal 186
} 
melawan hukum yang dilakukan dr. Wardhani Sp.THT dan RS Puri Cinere, hakim PN Cibinomg mengabulkan tuntutan sebagian tuntutan ganti rugi dengan perincian $70 \%$ kewajiban Tergugat 1 yaitu dokter dan $30 \%$ kewajiban Tergugat 2 yaitu pihak RS Puri Cinere. Putusan hakim tersebut ditolak oleh pihak tergugat dengan cara mengajukan kasasi. Jarak permohonan kasasi dengan penyampaian memori kasasi yang melewati tenggat waktu 14 hari sebagaimana diwajibkan dalam Undang-Undang Nomor 5 Tahun 2004, menyebabkan hak mengajukan kasasi gugur tandas majelis hakim.

Beberapa tahun belakang ini, baik media cetak maupun elektronik sudah semakin sering memberitakan mengenai pasien yang mengugat dan menuntut Rumah Sakit atas pelayanan kesehatan yang diterimanya.Gugatan hukum pada umumnya diajukan atas tuduhan telah terjadi malpraktek, kelalaian atau tindakan yang berlebihan dalam pelayanan terhadap pasien.Sejak tahun 1998 hingga Juli 2003, Yayasan Pemberdayaan Konsumen Indonesia menemukan kasus dugaan malpraktek sebanyak 254 kasus. Berdasarkan data Lembaga Bantuan Hukum (LBH) Jakarta saja, sedikitnya sepuluh orang mengadu ke LBH karena tindakan dokter atau petugas kesehatan yang merugikan. ${ }^{9}$ Jumlah tersebut semakin bertambah setiap tahunnya.Menurut Sabir Alwy, Wakil Ketua Majelis Kehormatan Disiplin Kedokteran Indonesia (MKDKI), jumlah dokter yang diadukan pasien akibat kepentingannya dirugikan karena tindakan dokter dari tahun ke tahun mengalami kenaikan, seperti melihat pada table berikut: ${ }^{10}$

9 Moh.Hatta, 2013, Hukum Kesehatan \& Sengketa Medik, Yogyakarta, Liberty, hal 244.

10 Sabir Alwy, 2011, Pasien yang Mengadukan Dokter ke MKDKI Jumlahnya Makin Banyak,,tersedia pada website www.detikhealth.com, diakses tanggal 23 Maret 2015.
Data yang masuk ke Lembaga Bantuan Hukum (LBH) Kesehatan sebanyak 405 kasus dalam beberapa tahun terakhir. Sebanyak 73 kasus diantaranya masuk ke dalam laporan kepolisian. ${ }^{11}$ Data di atas setidaknya memberikan gambaran bahwa kasus-kasus gugatan yang diajukan baik kepada Rumah Sakit maupun tenaga kesehatan yang karena tindakannya dalam memberikan pelayanan kesehatan telah merugikan pasien semakin hari semakin meningkat. Hal tersebut menunjukkan bahwa kesadaran hukum masyarakat semakin meningkat, yang terutama dirasakan sejak diberlakukannya Undang-Undang Nomor 8 Tahun 1999 Tentang Perlindungan Konsumen. Kesadaran hukum yang semakin tinggi di masyarakat ini akan berdampak pula dengan semakin meningkatnya tuntutan hukum kepada Rumah Sakit maupun tenaga kesehatan dalam pelayanan kesehatan dari tahun ke tahun.

Undang-undang Nomor 36 Tahun 2009 tentang Kesehatan Pasal 58 ayat (1) menyebutkan bahwa,"setiap orang berhak menuntut ganti rugi terhadap seseorang, tenaga kesehatan, dan/atau penyelenggara kesehatan yang menimbulkan kerugian akibat kesalahan atau kelalaian dalam pelayanan kesehatan yang diterimanya". Berdasarkan ketentuan tersebut, terlihat bahwa penuntutan ganti kerugian ini, baik sebagai diakibatkan karena kesalahan (kesengajaan) ataupun karena kelalaian dalam pelayanan kesehatan, dan penuntutan ditujukan kepada seseorang, tenaga kesehatan maupun

11 Tri Astuti Sugiyatmi, 2014. Kasus Yang Terjadi Antara Pasien Dan Rumah Sakit, Kasus Medis vs Mutu Layanan Kesehatan, tersedia dalam website www.lasmawatibutarbutar.blogspot.com, diakses tanggal 23 Maret 2015. 
pihak penyelenggara (Rumah Sakit). ${ }^{12}$ Sementara itu berdasarkan UU No. 44 Tahun 2009, penuntutan kerugian hanya ditujukan kepada pihak Rumah Sakit, yang diakibatkan secara khusus karena kelalaian tenaga kesehatan di Rumah Sakit. ${ }^{13}$ Pasal 46 UndangUndang Nomor 44 Tahun 2009 tentang Rumah Sakitmenyebutkan bahwa,"Rumah Sakit bertanggung jawab secara hukum terhadap semua kerugian yang ditimbulkan atas kelalaian yang dilakukan oleh tenaga kesehatan di Rumah Sakit".

Pada tahap mana kesalahan itu terjadi, apakah pada mempersiapkan atau mendistribusikan obat. Demikian juga pasien akan sulit menentukan apakah posisi seorang dokter atau dokter gigi atau tenaga kesehatan yang bekerja di rumah sakit, apakah bertindak sebagai atasan atau sebagai pembantu, apakah ia bawahan atau bukan. Demikian juga apakah tindakan yang dilakukan termasuk dalam kompetensi pelaku ataukah dilaksanakan dibawah pengawasan. ${ }^{14}$ Kenyataannya memang tidak mudah bagi seorang pasien untuk menggugat sebuah Rumah Sakit. Dalam hubungan antara Rumah Sakit dengan pasien, acapkali pasien berada pada posisi yang lemah, karena pasien sering mengabaikan hak-haknya karena sakit, tidak dapat berpikir, lemah, dan was-was akan penyakitnya. Ditambah lagi karakter pasien di Indonesia yang cenderung menerima dan pasrah pada semua upaya pelayanan kesehatan di Rumah Sakit. Shanti Marina dalam gugatannya meminta pertanggungjawaban akibat perbuatan

Setya Wahyudi, Op.Cit.,hal 487.

Ibid,.

14 Syahrul Machmud, 2008, Penegakan Hukum Dan Perlindungan Hukum Bagi Dokter Yang Diduga Melakukan Medikal Malpraktek, Bandung, Mandar Maju, hal 107. melawan hukum yang dilakukan oleh $d r$. Wardhani Sp. THT dan Rumah Sakit Puri Cinere, adalah salah satu contoh dari sedikitnya kasus gugatan pasien terhadap dokter dan Rumah Sakit yang dimenangkan oleh pasien.Yang pada akhirnya dokter dan Rumah Sakit harus membayar ganti rugi secara tanggung renteng atas kerugian yang dialami oleh pasien.

Sengketa medik adalah sengketa yang terjadi antara pasien atau keluarga pasien dengan tenaga kesehatan atau antara pasien dengan Rumah Sakit atau fasilitas kesehatan. ${ }^{15} \mathrm{Bila}$ terjadi sengketa medis, biasanya pasien akan mengadukannya kepada instansi kepolisian dan juga media massa. Biasanya kemudian, suatu kasus yang belum terbukti seringkali menjadi sebuah pemberitaan yang besar. Akibatnya sudah dapat diduga pers menghukum tenaga kesehatan mendahului pengadilan dan menjadikan tenaga kesehatan sebagai bulan-bulanan, yang tidak jarang merusak reputasi nama dan juga karir tenaga kesehatan ini.Sementara itu pengaduan ke kepolisian baik di tingkat Polsek, Polres maupun Polda diterima dan diproses seperti layaknya sebuah perkara pidana.Menggeser kasus perdata ke ranah pidana, penggunaan Pasal yang tidak konsisten, kesulitan dalam pembuktian fakta hukum serta keterbatasan pemahaman terhadap seluk beluk medis oleh para penegak hukum di hampir setiap tingkatan menjadikan sengketa medik terancam terjadinya disparitas pidana.Upaya penyelesaian sengketa melalui peradilan umum yang selama ini

15 M. Nasser, Sengketa Medis Dalam Pelayanan Kesehatan, tersedia pada website www.kebijakankesehatanindonesia.net, diakses tanggal 30 November 2014, hal 3. 
ditempuh tidak dapat memuaskan pihak pasien, karena putusan hakim dianggap tidak memenuhi rasa keadilan pasien atau Jaksa Penuntut Umum maupun Hakim untuk membuktikan adanya kesalahan dokter. Kesulitan pembuktian dikarenakan minimnya pengetahuan mereka mengenai permasalahan-permasalahan tehnis sekitar pelayanan medik. ${ }^{16} \mathrm{M}$. Nasser dalam tulisannya mengenai Sengketa Medis Dalam Pelayanan Kesehatan yang menyebutkan sebagai berikut:

"Dugaan kelalaian medik di negara commom law memakai pendekatan tort, dimana secara hukum lebih banyak menggunakan pendekatan perdata.Hal ini berbeda dengan sistem hukum di Indonesia yang menempatkan perkara dugaan kelalaian medik sebagai pelanggaran etika profesi, disiplin profesi ataupun hukum pada umumnya baik perdata maupun pidana."

Bila proses sengketa medis tetap dilanjutkan melalui proses litigasi maka akan banyak kerugian yang dapat terjadi atau ganti rugi yang diharapkan tidak dapat dikabulkan. Dari sudut dokter, tenaga kesehatan dan atau Rumah Sakit akan menyebabkan reputasinya menjadi rusak. Hasil putusan litigasi juga menyebabkan dokter maupun tenaga kesehatan akan bekerja dengan sangat berhati-hati yang pada akhirnya nanti mereka tidak akan berani mengambil suatu risiko dalam menjalankan profesinya, sehingga menyebabkan biaya kesehatan yang tinggi. Dari sudut pasien/ masyarakat yang mengugat litigasi sering menyebabkan biaya yang dikeluarkan lebih besar daripada ganti rugi yang pada akhirnya diterima oleh penggugat, dan seringkali pada akhirnya tidak membantu mengurangi penderitaan yang diterimanya. Kalaupun mendapatkan ganti rugi akibat kelalaian dalam pelayanan kesehatan maka seringkali tidak sebanding dengan kerugian yang dialami oleh pasien, baik berupa kecacatan pada anggota tubuhnya yang harus diderita seumur hidup bahkan adapula yang harus kehilangan nyawa orang yang dicintai.

\section{Ketentuan Pasal 46 Undang-undang} Nomor 44 Tahun 2009 tentang Rumah Sakit memberi peluang bagi pasien untuk mendapat ganti rugi apabila menderita kerugian yang diakibatkan kelalaian tenaga kesehatan di rumah sakit. Namun seperti telah diuraikan diatas, upaya tuntutan mendapatkan ganti rugi akibat kelalaian ini tidaklah mudah dan sering kali tidak berhasil.Oleh karena itu perlu kiranya lebih diperjelasbagi pihak Rumah Sakit, tenaga kesehatan maupun pasien ketentuan mengenai pertanggung jawaban akibat kelalaian dalam pelayanan kesehatan tersebut.Bagi Rumah Sakit perlu mengetahui bentuk kelalaian tenaga kesehatan yang menjadi tanggung jawab rumah sakit dan bentuk kelalaian tenaga kesehatan yang tidak menjadi tanggung jawab Rumah Sakit. ${ }^{17}$ Berdasarkan latar belakang masalah diatas, penulis tertarik untuk mengkaji lebih dalam masalah tersebut dan merumuskan dalam judul: "Kajian Yuridis Tanggung Jawab Perdata Rumah Sakit Akibat Kelalaian Dalam Pelayanan Kesehatan".

\section{PERUMUSAN MASALAH}

Berdasarkan padalatar belakang masalah diatas, dirumuskan masalah tersebut sebagai berikut: Pertama, Bagaimanakah tanggung jawab perdata Rumah Sakit akibat kelalaian dalam pelayanan kesehatan; Kedua, Bagaimanakah analisis ganti rugi dari pertanggung- 
jawaban Rumah Sakit akibat kelalaian dalam pelayanan kesehatan dalam putusan Mahkamah Agung Nomor 957 K/Pdt/2006.

\section{METODE PENELITIAN}

Metode pendekatan yang digunakan adalah yuridis normatif atau penelitian hukum yang hanya meneliti bahan pustaka sehingga disebut juga penelitian hukum kepustakaan. ${ }^{18}$ Adapun pendekatan lain yang digunakan adalah pendekatan Analitis (Analytical Approach). ${ }^{19}$ Spesifikasi penelitian deskriptif, yaitu penelitian yang selain melukiskan keadaan, obyek, atau peristiwa juga keyakinan tertentu akan diambil kesimpulan-kesimpulan dari obyek persoalan yang dikaitkan dengan teori-teori hukum dan praktek hukum positif yang menyangkut permasalahannya. ${ }^{20}$ Penelitian ini dianalisis dengan menggunakan metode analisis deskriptif kualitatif.

\section{PEMBAHASAN}

\section{Tanggung Jawab Perdata Rumah Sakit akibat Kelalaian Dalam Pelayanan Kesehatan}

Undang-Undang Rumah Sakit dibuat untuk menjamin dan lebih memberikan kepastian dalam penyelenggaraan kesehatan di Rumah Sakit. Bagi pasien, Undang-Undang Rumah Sakit memberi kepastian hukum bahwa hakhaknya dalam pelayanan kesehatan di Rumah Sakit akan terpenuhi, demikian juga bagi tenaga kesehatan yang bekerja di Rumah Sakit bahwa dengan diberlakukannya Undang-Undang Rumah Sakit maka mereka akan lebih tenang bekerja karena telah jelas terlindungi oleh payung hukum. Sementara itu bagi pihak Rumah

18 Soerjono Seokanto dan Sri Mamudji, 2007, Penelitian Hukum Normatif, Jakarta, PT RajaGrafindo Persada, hal 14.
Sakit, Undang-Undang Rumah Sakit memberikan kepastian hukum sehingga Rumah Sakit dapat melaksanakan fungsi manajemennya dengan lebih optimal, dapat lebih mengontrol dan mengatur pelayanan kesehatan yang menjadi tanggung jawabnya dengan sebaik mungkin, sehingga kejadian-kejadian yang dapat merugikan pasien dapat dihindari.

Pasal 46 Undang-Undang Rumah Sakit merupakan salah satu bukti dari terjaminnya hakhak pasien, terlindunginya tenaga kesehatan, dan terjaminnya pelayanan kesehatan di Rumah Sakit. Pasal 46 Undang-Undang Rumah Sakit telah menjamin bagi pasien bahwa pasien dapat meminta pertanggungjawaban kepada Rumah Sakit apabila mengalami kerugian akibat kelalaian yang dilakukan oleh tenaga kesehatan dalam memberikan pelayanan kesehatan. Hal ini sesuai dengan ketentuan yang tercantum dalam Undang-undang Nomor 36 Tahun 2009 tentang Kesehatan Pasal 58 yang dengan jelas menyebutkan bahwa pasien dapat menggugat atau menuntut pertangungjawaban kepada tenaga kesehatan maupun kepada badan layanan kesehatan apabila mengalami kerugian akibat kesengajaan maupun kelalaian dalam pelayanan kesehatan.

Ketentuan Pasal 46 Undang-Undang Rumah Sakit dengan jelas membatasi bahwa Rumah Sakit hanya akan bertanggung jawab terhadap kerugian yang dialami pasien akibat kelalaian yang dilakukan oleh petugas kesehatan yang dilakukan dalam memberikan pelayanan kesehatan dan sesuai dengan ranah tanggung jawabnya di Rumah Sakit. Berdasarkan ketentuan pasal diatas kerugian yang diakibatkan

19 Johnny Ibrahim, 2005, Teori dan Metodologi Penelitian Hukum Normatif,Malang, Bayumedia,hal 310.

20 Ronny Hanitijo Sumitro, 2007, Metode Penelitian Hukum dan Jurimetri, Jakarta, PT Raja Grafindo Persada, hal 15. 
karena kesengajaan ataupun resiko medik yang dilakukan oleh petugas kesehatan dalam pelayanan kesehatan di Rumah Sakit tidaklah menjadi tanggung jawab Rumah Sakit dan menjadi tanggung jawab petugas kesehatan yang bersangkutan. Sehingga pasien tidak dapat menggugat Rumah Sakit untuk ikut bertanggung jawab akibat kesengajaan maupun resiko medik dalam pelayanan kesehatan yang dilakukan oleh petugas kesehatan walaupun itu terjadi di dalam Rumah Sakit itu sendiri.

Bagi pasien, ketentuan Pasal 46 ini memberikan angin segar bahwa pasien dapat pula menggugat Rumah Sakit karena kerugian yang dialami akibat kelalaian dalam pelayanan kesehatan yang dilakukan oleh tenaga kesehatan pada saat bertugas di Rumah Sakit. Sehingga, dalam hal ini pasien lebih bisa mendapat kepastian ganti rugi daripada hanya menggugat petugas kesehatan yang bersangkutan. Hal ini yang dilakukan oleh Shanti Marina warga Perumahan Bumi Karang Indah, Lebak Bulus Kecamatan Cilandak, Jakarta Selatan yang menderita kecacatan, yaitu suaranya menjadi sengau / bindeng setelah menjalani operasi amandel yang dilakukan oleh $d r$. Wardhani Sp.THT di Rumah Sakit Puri Cinere. Padahal sebelum operasi suara pasien dalam keadaaan baik/normal. Dalam gugatannya Shanti Marina meminta pertanggungjawaban atas perbuatan melawan hukum yang dilakukan $\mathrm{dr}$. Wardhani Sp.THT dan RS Puri Cinere. Hakim PN Cibinong mengabulkan sebagian tuntutan ganti rugi yang diajukan oleh Shanti Marina. Hakim PN Cibinong pun memutuskan bahwa Shanti Marina mendapatkan ganti rugi dengan perincian $70 \%$ kewajiban Tergugat 1 yaitu dokter dan $30 \%$ kewajiban Tergugat 2 yaitu pihak RS Puri Cinere. Kasus gugatan tersebut menjadi salah satu contoh bahwa Rumah Sakit dapat pula dimintakan pertanggungjawaban akibat kerugian yang diderita oleh pasien dalam pelayanan kesehatan di Rumah Sakit.

Bagi Rumah Sakit ketentuan Pasal 46 Undang-Undang Rumah Sakit tersebut memberi kejelasan bahwa Rumah Sakit dapat dituntut hanya akibat kelalaian yang dilakukan oleh tenaga kesehatan yang dilakukan di Rumah Sakit. Hal ini jelas menguntungkan Rumah Sakit. Kerugian yang diakibatkan kesalahan karena kesengajaan yang dilakukan oleh petugas kesehatan tidak menjadi tanggung jawab Rumah Sakit, melainkan menjadi tanggung jawab tenaga kesehatan yang bersangkutan walaupun dilakukan di dalam Rumah Sakit tersebut.

Rumah Sakit dan pasien yang menderita kerugian akibat kelalaian dalam pelayanan kesehatan di Rumah Sakit adalah sama-sama subyek hukum yang bisa dikenai hak dan kewajiban. Hukum yang mengatur hubungan antara satu subjek hukum dengan subjek hukum lain adalah hukum privat (hukum perdata) di mana ranahnya adalah perlindungan hak. Maka Undang-Undang yang mengatur peristiwa hukum ini adalah KUHPerdata ialah Pasal 1367 ayat (3) yang bunyinya:

"Majikan-majikan dan mereka yang mengangkat orang-orang lain untuk mewakili urusan-urusan mereka, adalah bertanggung jawab tentang kerugian yang diterbitkan oleh pelayan-pelayan atau bawahan-bawahan mereka di dalam melakukan pekerjaan untuk mana orangorang ini dipakainya."

M.A. Moegni Djojodirdjo menuliskan dalam bukunya Perbuatan Melawan Hukum bahwa : Pertanggungjawaban majikan dalam Pasal 1367 ayat (3) KUHPerdata tidak hanya mengenai tanggung jawab dalam ikatan kerja saja, termasuk kepada seseorang yang di luar ikatan 
kerja telah diperintahkan seorang lain untuk melakukan sesuatu pekerjaan tertentu, asal saja orang yang diperintahkan melakukan pekerjaan tersebut melakukan pekerjaannya secara berdiri sendiri-sendiri baik atas pimpinannya sendiri atau telah melakukan pekerjaan tersebut atas petunjuknya. Sebagaimana yang dimaksud dalam Pasal 1601 a KUHPerdata, pertanggungjawaban majikan atas perbuatan-perbuatan melawan hukum dari karyawan - karyawannya yakni: "Persetujuan perburuhan adalah persetujuan dengan mana pihak yang satu, si buruh, mengikatkan dirinya untuk di bawah perintahnya pihak yang lain, si majikan, untuk sesuatu waktu tertentu melakukan pekerjaan dengan menerima upah".

Membandingkan bunyi Pasal 46 UndangUndang Nomor 44 Tahun 2009 tentang Rumah Sakit dengan Pasal 1367 KUHPerdata ayat (3) di atas, dapat diambil kesimpulan bahwa Pasal 46 Undang-Undang Nomor 44 tahun 2009 tentang Rumah Sakit adalah derivate atau turunan dari Pasal 1367 KUHPerdata ayat (3) yang berlaku khusus untuk kalangan Rumah Sakit, atau Pasal 46 Undang-Undang Nomor 44 Tahun 2009 bersifat lex spesialis.

Ketentuan Pasal diatas juga sejalan dengan ketentuan dari doktrin respondeat superior. Doktrin respondeat superior mengandung makna bahwa seorang majikan adalah orang yang berhak untuk memberikan instruksi dan mengontrol tindakan bawahannya, baik atas hasil yang dicapai maupun tentang cara yang digunakan. Di samping itu dengan perkembangan hukum kesehatan dan kecanggihan teknologi kedokteran, rumah sakit pun tidak dapat melepaskan diri dari tanggung jawab pekerjaan yang dilakukan oleh pegawainya, termasuk apa yang diperbuat oleh para medis. ${ }^{21}$

Secara teoritis rumah sakit terikat pada doktrin respondeat superior, namun doktrin ini tidak dapat diterapkan begitu saja, karena untuk penerapannya harus terlebih dulu dipenuhi syarat-syarat tertentu, seperti harus adanya hubungan kerja antara atasan dengan bawahan dan sikap tindak bawahan harus pula dalam ruang lingkup pekerjaan yang ditugaskan kepadanya. Hubungan kerja dianggap ada, apabila atasan mempunyai hak secara langsung mengawasi dan mengendalikan aktivitas bawahan dalam melakukan tugas-tugasnya, dalam hal ini pekerjaan yang dilakukan harus merupakan suatu wujud perintah yang diberikan oleh atasan. ${ }^{22}$

Tanggung gugat hukum yang ditujukan kepada Rumah Sakit sebagai pemberi sarana pelayanan kesehatan tidaklah menggugurkan tanggung jawab hukum dari petugas kesehatan yang melakukan kelalaian dalam pelayanan kesehatan. Petugas kesehatan yang melakukan kelalaian yang mengakibatkan timbulnya kerugian bagi pasien dalam pelayanan kesehatan di Rumah Sakit tetap dikenai tanggung jawab hukum, sebagaimana diatur dalam Pasal 1365 KUHPerdata yaitu, "Tiap perbuatan melanggar hukum yang membawa kerugian kepada seorang lain mewajibkan orang yang karena salahnya menerbitkan kerugian itu mengganti kerugian tersebut". Tuntutan atau gugatan perdata yang dapat diajukan kepada Rumah Sakit (tanggung gugat hukum) seperti telah disebutkan sebelumnya adalah: 
a. Tanggung gugat berdasarkan wanprestasi atau cedera janji atau ingkar janji yang didasarkan pada contractual liability sebagaimana diatur dalam Pasal 1239 KUHPerdata.

b. Tanggung gugat berdasarkan perbuatan melanggar hukum (onrechtmatigedaad) sebagaimana diatur dalam ketentuan Pasal 1365 KUHPerdata.

Tuntutan atau gugatan perdata tersebut dapat diajukan semata-mata didasarkan pada wanprestasi, atau didasarkan pada perbuatan melawan hukum saja, namun dapat pula diajukan sekaligus yaitu secara wanprestasi dan perbuatan melawan hukum secara bersamaan. Tentunya dasar tuntutan harus jelas mana yang wanprestasi dan mana yang perbuatan melawan hukum, karena pencampuran antara wanprestasi dan perbuatan melawan hukum dapat berakibat gugatan atau tuntutan itu dinyatakan kabur atau obscuurlibel dan gugatan dinyatakan tidak dapat diterima atau niet on vankerlijke verklart.

\section{Analisis Ganti Rugi dari Pertanggungg- jawaban Perdata Rumah Sakit Akibat Kela- laian dalam Pelayanan Kesehatan}

Kitab Undang-Undang Hukum Perdata menyebutkan pada Pasal 1365 KUH Perdata yang menyebutkan bahwa, "Tiap perbuatan yang melanggar hukum dan membawa kerugian kepada orang lain, mewajibkan orang yang menimbulkan kerugian itu karena kesalahannya untuk menggantikan kerugian tersebut". Pasal diatas memuat ketentuan bahwa terdapat hubungan kausal antara perbuatan dan kerugian.
Dari segi kacamata yuridis, konsep ganti rugi dalam hukum dikenal dalam dua bidang hukum, yaitu sebagai berikut: ${ }^{23}$

a. Konsep ganti rugi karena wanprestasi;

b. Konsep ganti rugi karena perikatan berdasarkan undang-undang termasuk ganti rugi karena perbuatan melawan hukum.

Penuntutan ganti rugi atas kerugian yang dialami oleh pasien dalam pelayanan kesehatan baik oleh pasien sendiri maupun keluarganya telah diatur dalam Undang-Undang Nomor 36 Tahun 2009 tentang Kesehatan yang dirumuskan dalam Pasal 58 ayat 1 yang menyebutkan,

"Setiap orang berhak menuntut ganti rugi terhadap seseorang, tenaga kesehatan, dan/atau penyelenggara kesehatan yang menimbulkan kerugian akibat kesalahan atau kelalaian dalam pelayanan kesehatan yang diterimanya".

Terdapat dua bentuk ganti rugi akibat perbuatan melawan hukum yang biasa digunakan dalam gugatan pasien kepada tenaga kesehatan maupun Rumah Sakit dalam beberapa kasus, yaitu ganti rugi Materiil dan ganti rugi Immateriil:

1). Ganti Rugi Materiil

Kerugian materiil adalah kerugian yang nyata-nyata diderita oleh korban dan jumlahnya dapat diukur secara matematis.

2). Ganti Rugi Immateriil

Kerugian imateriil merupakan kerugian pihak korban yang tidak dapat diukur jumlahnya. Ganti rugi immateriil dapat

23 Munir Fuady, 2013, Perbuatan Melawan Hukum Pendekatan Kontemporer, Bandung, Citra Aditya Bakti, hal. 134. 
berupa penderitaan sakit atau kesakitan, kesedihan, ketakutan, kehilangan kesenangan, kehilangan harapan, kehilangan bagian tubuh atau cacat, bahkan sampai kematian pasien bukan kerugian yang dapat dituntut atas dasar wanprestasi. Ganti rugi immateriil ini hanya dapat dibebankan terhadap kerugian karena perbuatan melawan hukum dan tidak layak diterapkan atas kerugian yang disebabkan oleh wanprestasi kontrak.

Ketentuan ganti rugi berdasarkan gugatan wanprestasi berdasarkan Pasal $1246 \mathrm{KUH}$ Perdata akan memberikan kerugian berupa biaya, kerugian dan bunga. Namun ketentuan pertanggungjawaban berdasarkan gugatan wanprestasi adalah adanya ingkar janji atau tidak dipenuhinya isi perikatan dalam hal ini adalah ingkar janji atau tidak terpenuhinya perjanjian terapeutik. Perikatan atau perjanjian terapeutik antara dokter atau tenaga kesehatan dengan pasien adalah dalam hal prestasi yang harus dipenuhi dokter atau tenaga kesehatan berupa kesungguhan, kecermatan, kehati-hatian dengan didasarkan pada keilmuan dan keterampilan serta pengalaman sebagai dokter maupun tenaga kesehatan dalam melakukan tindakan medis. Dimana, dokter maupun tenaga kesehatan haruslah memenuhi standar profesi, standar pelayanan medis maupun standar operasional prosedur, apabila ketiga hal tersebut terpenuhi maka dokter maupun petugas kesehatan lain dapat terbebas dari gugatan maupun tuntutan hukum. Berdasarkan uraian diatas maka gugatan berdasarkan wanprestasi maka ganti kerugian yang didapatkan oleh pasien adalah ganti kerugian berdasarkan isi perjanjian terapeutik yang telah disetujui oleh pasien sebelumnya dalam mendapatkan pela- yanan kesehatan. Dalam bentuk ganti rugi, maka ganti rugi berdasarkan wanprestasi dalam wujud ganti rugi materiil yaitu kerugian yang nyata-nyata diderita oleh korban dan jumlahnya dapat diukur secara matematis. Ganti rugi materiil ini sesuai dengan perjanjian terapeutik yang telah disetujui pasien sebelumnya.

Besarnya ganti rugi yang diminta ataupun yang diterima tidak ditentukan secara tegas dalam KUHPerdata. Pasal 1365 KUHPerdata menentukan kewajiban pelaku perbuatan melawan hukum untuk membayar ganti rugi, namun tidak ada pengaturan lebih lanjut mengenai ganti kerugian tersebut. Selanjutnya Pasal 1371 KUHPerdata memberikan sedikit pedoman untuk itu dengan menyebutkan:

"Menyebabkan luka atau cacat anggota badan seseorang dengan sengaja atau karena kurang hati-hati, memberi hak kepada si korban selain untuk menuntut penggantian biaya pengobatan, juga untuk menuntut penggantian kerugian yang disebabkan oleh luka atau cacat badan tersebut. Juga penggantian kerugian ini dinilai menurut kedudukan dan kemampuan kedua belah pihak dan menurut keadaan. Ketentuan terakhir ini pada umumnya berlaku dalam hal menilai kerugian yang ditimbulkan oleh suatu kejahatan terhadap pribadi seseorang".

KUHPerdata tidak dengan tegas atau bahkan tidak mengatur secara rinci tentang ganti rugi tertentu, atau tentang salah satu aspek dari ganti rugi, maka hakim mempunyai kebebasan untuk menerapkan ganti rugi tersebut sesuai dengan asas kepatutan, sejauh hal tersebut memang dimintakan oleh pihak penggugat. Justifikasi terhadap kebebasan hakim ini adalah karena penafsiran kata rugi, biaya dan bunga tersebut sangat luas dan dapat mencakup hampir segala hal yang bersangkutan dengan ganti rugi. 
Pedoman selanjutnya dapat ditemukan pada Pasal 1372 KUHPerdata yang menyatakan bahwa, "... Dalam menilai satu sama lain hal, Hakim harus memperhatikan kasar atau tidaknya penghinaan begitu pula pangkat, kedudukan dan kemampuan kedua belah pihak dan keadaan". Pada pasal 1372 KUHPerdata ditekankan bahwa dalam memutuskan ganti rugi yang diterima oleh pasien dalam gugatannya baik kepada tenaga kesehatan maupun kepada Rumah Sakit, Hakim memperhatikan kedudukan, kemampuan maupun keadaan tergugat dan penggugat dengan tetap mempertimbangkan dasar keadilan bagi keduanya.

Kasus Shanti Marina yang menggugat secara perdata dr. Warhdani Sp.THT dan Rumah Sakit Cinere untuk mendapatkan ganti rugi akibat penderitaan yang telah dialaminya telah sesuai dengan ketentuan Pasal 58 ayat (1) UndangUndang Nomor 36 Tahun 2009 tentang Kesehatan dan Pasal 46 Undang-Undang Nomor 44 Tahun 2009 tentang Rumah Sakit. Gugatan perdata yang diajukan berdasarkan perbuatan melawan hukum pun telah tepat adanya karena dengan demikian Shanti Marina dapat mengajukan tuntutan ganti rugi materiil dan immaterial.

Putusan Hakim Pengadilan Negeri Cibinong dan diperkuat dengan putusan Mahkamah Agung Nomor 957 K/Pdt/2006 dengan mengabulkan tuntutan ganti rugi Shanti Marina terhadap dr. Warhdani Sp.THT dan Rumah Sakit Puri Cinere dan dibayar secara tanggung renteng antara tergugat I dan tergugat II telah cukup memenuhi rasa keadilan bagi Shanti Marina sebagai penggugat atas penderitaan yang harus dialami akibat kelalaian dalam pelayanan kesehatan yang diterimanya. Hakim Pengadilan Negeri Cibinong mengabul- kan sebagian tuntutan ganti rugi Shanti Marina terhadap dr. Warhdani Sp.THT dan Rumah Sakit Puri Cinere berdasarkan pertimbangan bahwa dr. Warhdani Sp.THT telah melakukan perbuatan melawan hukum dan pihak Rumah Sakit Puri Cinere turut bertanggungjawab atas perbuatan melawan hukum yang dilakukan dokter Warhdani Sp.THT tersebut, serta menghukum secara tanggung renteng untuk membayar ganti rugi material dan immaterial dengan perincian $70 \%$ kewajiban dokter dan 30\% kewajiban Rumah Sakit. Seperti telah diuraikan diatas bahwa dalam KUHPerdata belum mengatur secara jelas mengenai ketentuan besaran ganti rugi yang diterima oleh pasien atas kerugian yang dideritanya, maka besaran ganti kerugian ditentukan oleh hakim dengan dasar pertimbangan Pasal 1372 KUHPerdata, Pasal 1371 KUHPerdata dengan keadilan.

\section{PENUTUP}

\section{Simpulan}

Pertama, tanggung Jawab Perdata Rumah Sakit atas tindakan kelalaian tenaga kesehatan di Rumah Sakit yang menyebabkan kerugian pada pasien sesuai dengan ketentuan dari Pasal 1367 ayat (3) KUHPerdata dan Pasal 46 Undang-Undang Nomor 44 Tahun 2009 tentang Rumah Sakit. Hal tersebut sesuai juga dengan doktrin responden superior, dan juga asas vicariuous liability yaitu Rumah Sakit bertanggung gugat atas kelalaian yang dilakukan oleh tenaga kesehatan yang bekerja dalam kedudukan sebagai employee. Ketentuan perundang-undangan tersebut memberi nilai lebih baik bagi pasien, Tenaga Kesehatan maupun Rumah Sakit. Ketentuan Pasal 46 merupakan dasar yuridis bagi pasien untuk meminta pertanggungjawaban Rumah Sakit apabila pasien 
menderita kerugian akibat kelalaian tenaga kesehatan. Bagi tenaga kesehatan pasal ini memberikan perlindungan hukum, karena Rumah Sakit ikut bertanggung jawab seandainya tenaga kesehatan yang bersangkutan berbuat suatu kelalaian. Ketentuan Pasal 46 ini juga memberikan keuntungan bagi Rumah Sakit, karena Rumah Sakit hanya bertanggung jawab sebatas akibat kelalaian tenaga kesehatan saja, dan tidak bertanggung jawab terhadap kesalahan karena kesengajaan yang dilakukan tenaga kesehatan di Rumah Sakit.

Kedua, tanggung jawab hukum perdata Rumah Sakit akibat kelalaian tenaga kesehatan di Rumah Sakit berupa pertanggungjawaban berdasarkan perbuatan melawan hukum dan pertanggung jawaban berdasarkan wanprestasi. Kedua bentuk tanggung gugat tersebut bergantung pada pasien akan menuntut gugatan berdasarkan yang mana, karena pembuktian hukumnya juga berbeda. Konsep ganti rugi yang diterima pasien dalam tanggung gugat Rumah Sakit akibat kerugian karena kelalaian tenaga kesehatan berbeda tergantung dari gugatan hukum yang diajukan, berdasarkan perbuatan melawan hukum ataukah berdasarkan wanprestasi. Ganti rugi berdasarkan gugatan akibat perbuatan melawan hukum lebih memberi keadilan bagi pasien maupun keluarganya yang menderita kerugian akibat kelalaian oleh tenaga kesehatan karena dapat menuntut ganti rugi materiil maupun immateriil, sedangkan bila berdasarkan wanprestasi maka tuntutan ganti rugi hanya dapat mengganti kerugian materiil saja. Putusan Mahkamah Agung Nomor 957 $\mathrm{K} / \mathrm{Pdt} / 2006$ yang menguatkan keputusan PN Cibinong yang mengabulkkan gugatan dari Shanti Marina atas perbuatan melawan hukum akibat kelalaian dalam pelayanan kesehatan yang dilakukan oleh dr.Wardhani Sp.THT dan RS Puri Cinere telah sesuai dengan ketentuan dari Pasal 1367 KUHPerdata ayat (3) dan Pasal 46 Undang-Undang Rumah Sakit, dan sesuai juga doktrin respondeat superior demikian pula sesuai dengan ketentuan asas vicarious liability.

\section{Saran}

Pentingnya sosialisasi ketentuan Pasal 46 Undang-Undang Nomor 44 Tahun 2009 tentang Rumah Sakit kepada pihak Rumah Sakit, tenaga Kesehatan, dan kepada masyarakat. Perlu dibuat peraturan pelaksana ketentuan Pasal 46 Undang-Undang Rumah Sakit dimana Rumah Sakit bertanggungjawab terhadap tindakan kelalaian tenaga kesehatan yang menyebabkan kerugian bagi pasien.

\section{DAFTAR PUSTAKA}

\section{Buku}

Astuti, Endang Kusuma, 2009,Transaksi Terapeutik Dalam Upaya Pelayanan Medis Di Rumah Sakit, Bandung, PT Citra Aditya Bakti, hal. 51. Dikutip dari Panitia Etika Rumah Sakit, 1991, "Etika Rumah Sakit di Rumah Sakit Dr. Cipto Mangunkusumo", Jakarta.

Fuady, Munir, 2013, Perbuatan Melawan Hukum Pendekatan Kontemporer, Bandung, Citra Aditya Bakti.

Hatta, Moh., 2013, Hukum Kesehatan \& Sengketa Medik, Yogyakarta, Liberty.

Ilyas, Amir, 2014,Pertanggungjawaban Pidana Dokter Dalam Malpraktik Medik Di Rumah Sakit,Yogyakarta, Rangkang Education dan Republik Institute.

Ibrahim, Johnny, 2005, Teori dan Metodologi Penelitian Hukum Normatif,Malang, Bayumedia.

Machmud, Syahrul, 2008, Penegakan Hukum Dan Perlindungan Hukum Bagi Dokter Yang Diduga Melakukan Medikal Malpraktek, Bandung, Mandar Maju 
Nasution, Bahder Johan, 2005, Hukum Kesehatan Pertanggungjawaban Dokter, Jakarta, Rineka Cipta.

Sumitro, Ronny Hanitijo, 2007, Metode Penelitian Hukum dan Jurimetri, Jakarta, PT Raja Grafindo Persada.

Seokanto, Soerjono dan Sri Mamudji, 2007, Penelitian Hukum Normatif, Jakarta, PT RajaGrafindo Persada

Yustina, Endang Wahyati, 2012, Mengenal Hukum Rumah Sakit, Bandung, CV Keni Media.

\section{Jurnal}

Setya Wahyudi, 2011,Tanggung Jawab Rumah Sakit Terhadap Kerugian Akibat Kelalaian Tenaga Kesehatan Dan Implikasinya, Jurnal Dinamika Hukum Fakultas Hukum Universitas Jenderal Soedirman Volume 11 No.3;

Bambang Heryanto, 2010, "Malpraktik Dokter dalam Perspektif Hukum", Jurnal Dinamika Hukum, Vol.10 No.2 Mei 2010;

\section{Internet}

Sabir Alwy, 2011, Pasien yang Mengadukan Dokter ke MKDKI Jumlahnya Makin Banyak,tersedia pada website www.detikhealth.com, diakses tanggal 23 Maret 2015

Sugiyatmi, Tri Astuti, 2014. Kasus Yang Terjadi Antara Pasien Dan Rumah Sakit, Kasus Medis vs Mutu Layanan Kesehatan, tersedia dalam website www.lasmawatibutarbutar.blogspot.com, diakses tanggal 23 Maret 2015.

Nasser, M., Sengketa Medis Dalam Pelayanan Kesehatan, tersedia pada website www.kebijakankesehatanindonesia.net, diakses tanggal 30 November 2014. 